Article

\title{
PBDE: Structure-Activity Studies for the Inhibition of Hepatitis C Virus NS3 Helicase
}

Kazi Abdus Salam ' ${ }^{1}$, Atsushi Furuta ${ }^{2,3}$, Naohiro Noda ${ }^{2,3}$, Satoshi Tsuneda ${ }^{2}$, Yuji Sekiguchi ${ }^{3}$, Atsuya Yamashita ${ }^{4}$, Kohji Moriishi ${ }^{4}$, Masamichi Nakakoshi ${ }^{5}$, Hidenori Tani ${ }^{6}$, Sona Rani Roy ${ }^{7}$, Junichi Tanaka ${ }^{7}$, Masayoshi Tsubuki ${ }^{8, *}$ and Nobuyoshi Akimitsu ${ }^{1, *}$

1 Radioisotope Center, The University of Tokyo, 2-11-16 Yayoi, Bunkyo-ku, Tokyo 113-0032, Japan; E-Mail: salam_bio26@yahoo.com

2 Department of Life Science and Medical Bioscience, Waseda University, 2-2 Wakamatsu-cho, Shinjuku-ku, Tokyo 162-8480, Japan; E-Mails: atsushi.5961@ruri.waseda.jp (A.F.); stsuneda@waseda.jp (S.T.)

3 Biomedical Research Institute, National Institute of Advanced Industrial Science and Technology (AIST), 1-1-1 Higashi, Tsukuba, Ibaraki 305-8566, Japan;

E-Mails: noda-naohiro@aist.go.jp (N.N.); y.sekiguchi@aist.go.jp (Y.S.)

4 Department of Microbiology, Graduate School of Medicine and Engineering, University of Yamanashi, 1110 Shimokato, Chuo-shi, Yamanashi 409-3898, Japan;

E-Mails: atsuyay@yamanashi.ac.jp (A.Y.); kmoriishi@yamanashi.ac.jp (K.M.)

5 Faculty of Pharmaceutical Sciences, Toho University, 2-2-1 Miyama, Funabashi, Chiba 274-8510, Japan; E-Mail: nakakoshi@phar.toho-u.ac.jp

6 Research Institute for Environmental Management Technology, National Institute of Advanced Industrial Science and Technology (AIST), 16-1, Onogawa, Tsukuba, Ibaraki 305-8569, Japan; E-Mail: h.tani@aist.go.jp

7 Department of Chemistry, Biology and Marine Science, University of the Ryukyus, Nishihara, Okinawa 903-0213, Japan; E-Mails: sonarroy@gmail.com (S.R.R.); jtanaka@sci.u-ryukyu.ac.jp (J.T.)

8 Institute of Medical Chemistry, Hoshi University, Ebara 2-4-41, Shinagawa-ku, Tokyo 142-8501, Japan

* Authors to whom correspondence should be addressed; E-Mails: tsubuki@hoshi.ac.jp (M.T.); akimitsu@ric.u-tokyo.ac.jp (N.A.); Tel.: +81-3-5498-5793 (M.T.); Fax: +81-3-3787-0036 (M.T.); Tel.: +81-3-5841-2877 (N.A.); Fax: +81-3-5841-3049 (N.A.).

Received: 17 January 2014; in revised form: 5 March 2014 / Accepted: 13 March 2014 / Published: 2 April 2014 


\begin{abstract}
The helicase portion of the hepatitis $\mathrm{C}$ virus nonstructural protein 3 (NS3) is considered one of the most validated targets for developing direct acting antiviral agents. We isolated polybrominated diphenyl ether (PBDE) 1 from a marine sponge as an NS3 helicase inhibitor. In this study, we evaluated the inhibitory effects of PBDE (1) on the essential activities of NS3 protein such as RNA helicase, ATPase, and RNA binding activities. The structure-activity relationship analysis of PBDE (1) against the HCV ATPase revealed that the biphenyl ring, bromine, and phenolic hydroxyl group on the benzene backbone might be a basic scaffold for the inhibitory potency.
\end{abstract}

Keywords: hepatitis C virus; NS3 RNA helicase; marine sponge; polybrominated diphenyl ether

\title{
1. Introduction
}

Hepatitis $\mathrm{C}$ virus (HCV) is one of the major causative agents for hepatitis $\mathrm{C}$, which has caused an epidemic of liver fibrosis, cirrhosis, and hepatocellular carcinoma [1]. HCV infects more than 150 million people worldwide, and over 350,000 people die from HCV-related liver diseases each year [2]. The virus is undetectable for long periods of time, even decades, and replicates slowly without major complications. Therefore, most infected people are unaware they carry the virus. HCV is only transmitted via blood and blood products, while sexual and mother-to-child transmission is much less likely than for HIV infection [2].

The recently approved new treatment regimen for HCV infection is the combination of pegylated interferon and ribavirin with either telaprevir or boceprevir for genotype 1 infected patients. However, the emergence of viral resistance to the drugs as well as side effects, such as anemia, neutropenia, dysgeusia, rash, and anorectal discomfort, are the main concerns [3-6]. Despite intensive studies for the development of new antiviral drugs, $\mathrm{HCV}$ is still a major threat to human health. Therefore, there is an urgent need to develop new antiviral drugs with fewer side effects and the highest antiviral efficacy.

$\mathrm{HCV}$ is a single-stranded, positive-sense RNA virus in the Flaviviridae family [1,7]. Seven genotypes and more than 50 subtypes of HCV have been described [8]. The viral genome is $9.6 \mathrm{~kb}$ in length and contains one main open reading frame encoding an approximately 3,000 amino acid single polyprotein, flanked by a 5'-non-translated region (NTR) and a 3'-NTR. Once translation initiated by an internal ribosome entry site present at the $5^{\prime}$-NTR, host and viral proteases cleave the product into 10 individual viral mature proteins [9]. The structural proteins (envelope glycoproteins; E1 and E2) are responsible for receptor binding, thereby facilitating viral entry into the hepatocyte. The core protein (C) forms the viral nucleocapsid [10]. The nonstructural proteins p7, NS2, NS3, NS4A, NS4B, NS5A, and NS5B are involved in viral replication and packaging of the HCV genome. NS3 is a multifunctional protein that plays an important role in the viral life cycle. It has a serine protease (NS3/4A) activity at the N-terminal to cleave all downstream junctions, and helicase activity at the C-terminal to separate double-stranded RNA in a reaction fueled by ATP hydrolysis during replication of viral genomic RNA [11,12]. Although the precise role of the helicase activity in the viral life cycle 
is not well understood, a fully functional helicase is essential for HCV RNA replication. The helicase portion of NS3 is thus a valid target for the development of direct acting antiviral therapy.

The development of antiviral agents for the treatment of HCV infection has been focused on small molecule inhibitors of HCV infection that can act directly on viral targets or other host target proteins critical to HCV replication. The first two approved direct acting antiviral agents, telaprevir and boceprevir, are inhibitors of the NS3/4A protease activity [13]. However, very few compounds that inhibit the NS3 helicase function have been reported, and to the best of our knowledge, no helicase inhibitors have entered clinical trials. Thus there is still a great need in HCV research to develop novel NS3 helicase inhibitors.

The aim of this project was to identify a possible NS3 helicase inhibitor from marine natural products. In this study, we successfully obtained from marine sponge and identified hydroxylated polybrominated diphenyl ether OH-PBDE-47 (1), as a helicase inhibitor through a high-throughput screening method based on fluorescence resonance energy transfer (FRET). We also evaluated several commercially available compounds that are structurally related to PBDE (1) for the study of structureactivity relationships.

PBDEs have been found to exhibit antibacterial, antifungal, and antimicroalgal activities [14-19]. They inhibit a wide range of enzymes that are relevant to anticancer drug discovery such as inosine monophosphate dehydrogenase, guanosine monophosphate synthetase, and 15-lipoxygenase [20]. PBDEs have also been shown to exhibit inhibitory activities against the assembly of microtubule protein, the maturation of starfish oocytes [21] and Tie2 kinase [22]. In this research, we found a novel activity of PBDE in the specific inhibition of HCV NS3 helicase activity.

\section{Results and Discussion}

To screen potential NS3 helicase inhibitors from extracts of marine organisms, we used a highthroughput fluorescence helicase assay based on FRET [23]. Out of 41 extracts isolated (Table 1), PBDE (1) (Figure 1) exhibited the strongest inhibition (37\%) of NS3 helicase activity.

Table 1. Inhibitory effects of extracts from marine organisms on hepatitis $\mathrm{C}$ virus (HCV) nonstructural protein 3 (NS3) helicase activity.

\begin{tabular}{|c|c|c|c|c|c|}
\hline No. & $\begin{array}{l}\text { Sample } \\
\text { ID }\end{array}$ & $\begin{array}{l}\text { FRET } \\
(\%)^{a}\end{array}$ & $\begin{array}{c}\text { Possibly Contained } \\
\text { Molecule }\end{array}$ & Species & Location \\
\hline 1 & PM-35-1 & 85 & misakinolide & sponge (Theonella sp.) & $\begin{array}{c}\text { Tokashiki Island, } \\
\text { Okinawa }\end{array}$ \\
\hline 2 & PM-35-2 & 94 & & sponge (Theonella sp.) & $\begin{array}{c}\text { Tokashiki Island, } \\
\text { Okinawa }\end{array}$ \\
\hline 3 & PM-36-1 & 79 & & $\begin{array}{c}\text { gorgonian } \\
\text { (Euplexaura sp.) }\end{array}$ & $\begin{array}{c}\text { Tokashiki Island, } \\
\text { Okinawa }\end{array}$ \\
\hline 4 & PM-36-2 & 114 & & $\begin{array}{c}\text { gorgonian } \\
\text { (Euplexaura sp.) }\end{array}$ & $\begin{array}{c}\text { Tokashiki Island, } \\
\text { Okinawa }\end{array}$ \\
\hline 5 & PM-37-1 & 93 & briarane diterpenes & $\begin{array}{c}\text { gorgonian (Junceella } \\
\text { fragilis) }\end{array}$ & $\begin{array}{c}\text { Tokashiki Island, } \\
\text { Okinawa }\end{array}$ \\
\hline
\end{tabular}


Table 1. Cont.

\begin{tabular}{|c|c|c|c|c|c|}
\hline No. & $\begin{array}{l}\text { Sample } \\
\text { ID }\end{array}$ & $\begin{array}{l}\text { FRET } \\
(\%)^{a}\end{array}$ & $\begin{array}{c}\text { Possibly Contained } \\
\text { Molecule }\end{array}$ & Species & Location \\
\hline 6 & PM-37-2 & 115 & & $\begin{array}{c}\text { gorgonian (Junceella } \\
\text { fragilis) }\end{array}$ & $\begin{array}{c}\text { Tokashiki Island, } \\
\text { Okinawa }\end{array}$ \\
\hline 7 & PM-38-1 & 92 & hippuristanol & $\begin{array}{l}\text { gorgonian (Isis } \\
\text { hippuris) }\end{array}$ & $\begin{array}{c}\text { Tokashiki Island, } \\
\text { Okinawa }\end{array}$ \\
\hline 8 & PM-38-2 & 112 & & $\begin{array}{l}\text { gorgonian (Isis } \\
\text { hippuris) }\end{array}$ & $\begin{array}{c}\text { Tokashiki Island, } \\
\text { Okinawa }\end{array}$ \\
\hline 9 & PM-39-2 & 94 & & sponge (Petrosia sp.) & $\begin{array}{c}\text { Tokashiki Island, } \\
\text { Okinawa }\end{array}$ \\
\hline 10 & SR-1-1 & 37 & PBDE & $\begin{array}{l}\text { sponge (Dysidea } \\
\text { granulosa) }\end{array}$ & $\begin{array}{c}\text { Yonaguni Island, } \\
\text { Okinawa }\end{array}$ \\
\hline 11 & SR-2-2 & 92 & & sponge (Jaspis sp.) & $\begin{array}{c}\text { Yonaguni Island, } \\
\text { Okinawa }\end{array}$ \\
\hline 12 & SR-3-1 & 75 & petrosynol/petrosynone & sponge (Petrosia sp.) & $\begin{array}{c}\text { Yonaguni Island, } \\
\text { Okinawa }\end{array}$ \\
\hline 13 & SR-4-1 & 68 & strongylophorines & $\begin{array}{c}\text { sponge } \\
\text { (Strongylophora sp.) }\end{array}$ & $\begin{array}{c}\text { Yonaguni Island, } \\
\text { Okinawa }\end{array}$ \\
\hline 14 & SR-4-2 & 86 & & $\begin{array}{c}\text { sponge } \\
\text { (Strongylophora sp.) }\end{array}$ & $\begin{array}{c}\text { Yonaguni Island, } \\
\text { Okinawa }\end{array}$ \\
\hline 15 & SR-6-1 & 98 & sesquiterpenes & $\begin{array}{l}\text { soft coral (Clavularia } \\
\text { sp.) }\end{array}$ & $\begin{array}{c}\text { Yonaguni Island, } \\
\text { Okinawa }\end{array}$ \\
\hline 16 & SR-8-1 & 98 & & $\begin{array}{c}\text { soft coral } \\
\text { (Parerythropodium } \\
\text { sp.) }\end{array}$ & $\begin{array}{c}\text { Yonaguni Island, } \\
\text { Okinawa }\end{array}$ \\
\hline 17 & SR-8-2 & 84 & & $\begin{array}{c}\text { Yonaguni Island, } \\
\text { Okinawa }\end{array}$ & $\begin{array}{c}\text { Yonaguni Island, } \\
\text { Okinawa }\end{array}$ \\
\hline 18 & SR-10-1 & 112 & polyketide peroxides & sponge (Plakortis sp.) & $\begin{array}{c}\text { Yonaguni Island, } \\
\text { Okinawa }\end{array}$ \\
\hline 19 & SR-11-1 & 65 & & sponge (unidentified) & $\begin{array}{c}\text { Yonaguni Island, } \\
\text { Okinawa }\end{array}$ \\
\hline 20 & SR-12-2 & 135 & & sponge (unidentified) & $\begin{array}{c}\text { Yonaguni Island, } \\
\text { Okinawa }\end{array}$ \\
\hline 21 & SR-13-2 & 109 & & $\begin{array}{c}\text { sponge } \\
\text { (Pseudoceratina } \\
\text { purpurea) }\end{array}$ & $\begin{array}{c}\text { Yonaguni Island, } \\
\text { Okinawa }\end{array}$ \\
\hline 22 & SR-14-1 & 64 & swinholide & $\begin{array}{c}\text { sponge (Theonella } \\
\text { swinhoei) }\end{array}$ & $\begin{array}{c}\text { Yonaguni Island, } \\
\text { Okinawa }\end{array}$ \\
\hline 23 & SR-15-1 & 61 & & sponge (unidentified) & $\begin{array}{c}\text { Yonaguni Island, } \\
\text { Okinawa }\end{array}$ \\
\hline 24 & SR-16-1 & 92 & & sponge (unidentified) & $\begin{array}{c}\text { Yonaguni Island, } \\
\text { Okinawa }\end{array}$ \\
\hline 25 & SR-17-2 & 87 & & sponge (unidentified) & $\begin{array}{c}\text { Yonaguni Island, } \\
\text { Okinawa }\end{array}$ \\
\hline 26 & SR-19-2 & 131 & & sponge (Hyrtios sp.) & $\begin{array}{c}\text { Yonaguni Island, } \\
\text { Okinawa }\end{array}$ \\
\hline
\end{tabular}


Table 1. Cont.

\begin{tabular}{|c|c|c|c|c|c|}
\hline No. & $\begin{array}{c}\text { Sample } \\
\text { ID }\end{array}$ & $\begin{array}{l}\text { FRET } \\
(\%)^{a}\end{array}$ & $\begin{array}{c}\text { Possibly Contained } \\
\text { Molecule }\end{array}$ & Species & Location \\
\hline 27 & SR-21-1 & 155 & xestospongin & sponge (Xestospongia sp.) & $\begin{array}{c}\text { Yonaguni Island, } \\
\text { Okinawa }\end{array}$ \\
\hline 28 & SR-21-2 & 156 & & sponge (Xestospongia $\mathrm{sp})$. & $\begin{array}{c}\text { Yonaguni Island, } \\
\text { Okinawa }\end{array}$ \\
\hline 29 & SR-23-1 & 73 & avarol & sponge (Dysidea arenaria) & $\begin{array}{c}\text { Yonaguni Island, } \\
\text { Okinawa }\end{array}$ \\
\hline 30 & SR-23-2 & 82 & & sponge (Dysidea arenaria) & $\begin{array}{c}\text { Yonaguni Island, } \\
\text { Okinawa }\end{array}$ \\
\hline 31 & SR-24-1 & 123 & isocyanosesquiterpenes & sponge (Theonella sp.) & $\begin{array}{c}\text { Yonaguni Island, } \\
\text { Okinawa }\end{array}$ \\
\hline 32 & SR-26-2 & 102 & & sponge (unidentified) & $\begin{array}{c}\text { Yonaguni Island, } \\
\text { Okinawa }\end{array}$ \\
\hline 33 & SR-27-1 & 188 & & sponge (Leucetta sp.) & $\begin{array}{c}\text { Yonaguni Island, } \\
\text { Okinawa }\end{array}$ \\
\hline 34 & SR-27-2 & 171 & & sponge (Leucetta sp.) & $\begin{array}{c}\text { Yonaguni Island, } \\
\text { Okinawa }\end{array}$ \\
\hline 35 & SR-28-1 & 107 & & sponge (unidentified) & $\begin{array}{c}\text { Yonaguni Island, } \\
\text { Okinawa }\end{array}$ \\
\hline 36 & SR-29-2 & 145 & & sponge (Aaptos sp.) & $\begin{array}{c}\text { Yonaguni Island, } \\
\text { Okinawa }\end{array}$ \\
\hline 37 & SR-30-2 & 215 & agelasine & sponge (Agelas sp.) & $\begin{array}{c}\text { Yonaguni Island, } \\
\text { Okinawa }\end{array}$ \\
\hline 38 & SR-31-1 & 100 & hippuristanol & $\begin{array}{c}\text { gorgonian } \\
\text { (Isis hippuris) }\end{array}$ & $\begin{array}{c}\text { Yonaguni Island, } \\
\text { Okinawa }\end{array}$ \\
\hline 39 & SR-33-2 & 88 & & sponge (unidentified) & $\begin{array}{c}\text { Yonaguni Island, } \\
\text { Okinawa }\end{array}$ \\
\hline 40 & SR-34-1 & 125 & & $\begin{array}{c}\text { zoanthus } \\
\text { (Palythoa sp.) }\end{array}$ & $\begin{array}{c}\text { Yonaguni Island, } \\
\text { Okinawa }\end{array}$ \\
\hline 41 & SR-34-2 & 124 & palytoxin & $\begin{array}{c}\text { zoanthus } \\
\text { (Palythoa } \mathrm{sp} . \text { ) }\end{array}$ & $\begin{array}{c}\text { Yonaguni Island, } \\
\text { Okinawa }\end{array}$ \\
\hline
\end{tabular}

${ }^{a} \mathrm{NS} 3$ activity in the presence of marine organisms extract is expressed as a percentage of the control in the absence of extract $(100 \%)$.

Figure 1. Chemical structure of PBDE (1).

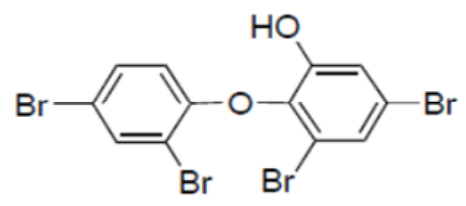

1

NS3 helicase hydrolyzes ATP as an energy source to drive the unwinding of dsRNA or dsDNA. Therefore, we measured the inhibitory effects of PBDE (1) on the ATPase activity of the helicase portion of NS3. A radioisotope labeling ATPase assay showed that PBDE (1) inhibited the hydrolytic release of inorganic phosphate from ATP with an $\mathrm{IC}_{50}$ of $80 \mu \mathrm{M}$ (Figure 2A,B). 
Figure 2. PBDE (1) inhibits NS3 ATPase activity. (A) Radioisotope labeling ATPase assay with NS3 (300 $\mathrm{nM}$ ) and various concentrations of PBDE. Lane 1 shows the negative control reaction. Lanes 2-3 show the reaction mixture containing only NS3 and DMSO. Lanes 4-17 show hydrolytic reactions with NS3 (300 nM) in the presence of PBDE as indicated. (B) Graphical representation of the inhibition results. The relative ATPase activity for control reactions was considered as $100 \%$. The average values are presented with error bars from duplicate assays.

A

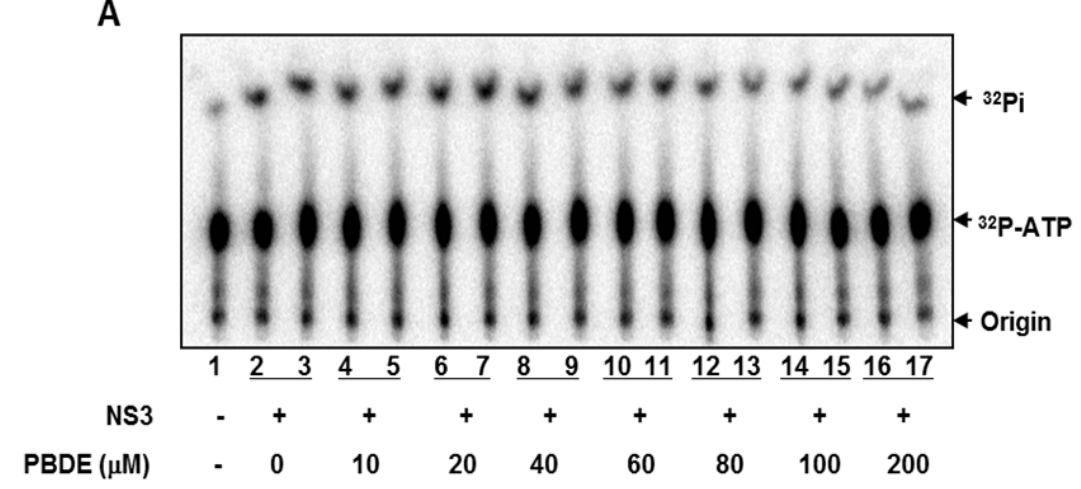

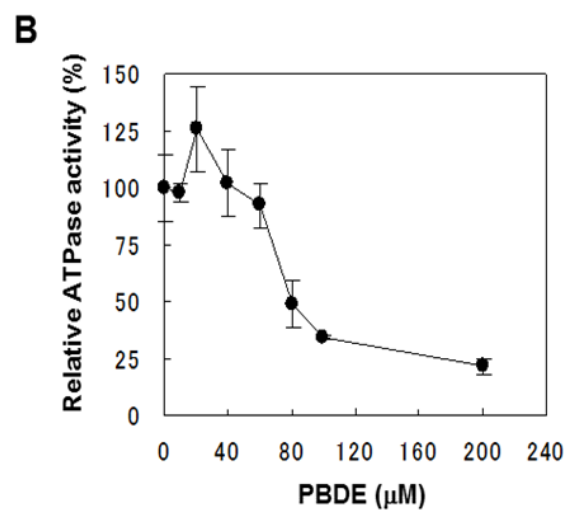

To examine the specificity of PBDE (1) for the inhibition of ATPase activity, we evaluated the ATP hydrolytic effect on bacterial alkaline phosphatase. PBDE (1) exhibited no inhibition (Figure 3), indicating that the inhibitory activity of PBDE (1) is specific to NS3.

Figure 3. Effect of PBDE (1) on the ATPase activity of bacterial alkaline phosphatase. The assay was conducted in the absence (DMSO) or presence of PBDE (1) (at the highest concentration tested, $200 \mu \mathrm{M})$. The data are expressed as the mean of three replicates with error bars representing standard deviation.

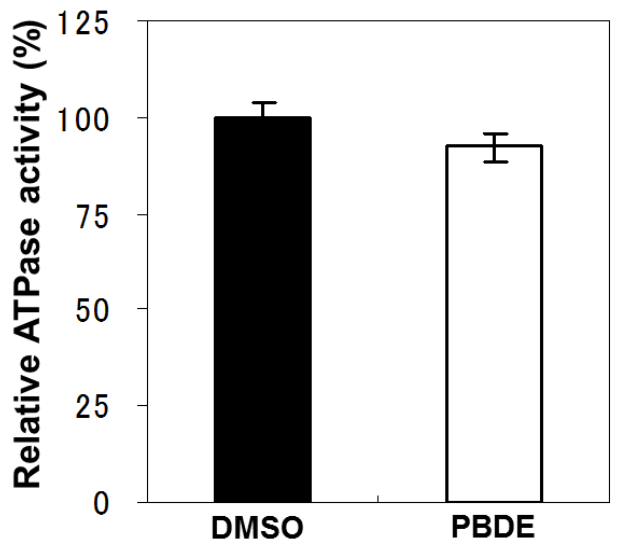

The binding of NS3 to ssRNA is required to initiate the unwinding activity of dsRNA during viral replication. We employed a gel mobility shift assay to characterize the inhibition of NS3 binding to RNA. PBDE (1) inhibited RNA binding of NS3 in a dose-dependent manner with an $\mathrm{IC}_{50}$ of $68 \mu \mathrm{M}$ (Figure 4A,B). Previous reports indicate that poly(U) RNA enhances the ATPase activity of NS3 [24]. Because PBDE (1) inhibits the RNA binding ability of NS3, we speculated that inhibition of NS3 ATPase activity by PBDE (1) could be mediated through the inhibition of poly(U) RNA binding. 
Therefore, we next performed ATPase assays including poly(U) RNA to determine the effects of poly $(\mathrm{U})$ with PBDE (1) near to its $\mathrm{IC}_{50}$ concentration. We found that PBDE (1) was significantly active in both the presence and absence of poly(U) (Figure 5A,B), suggesting that poly $(U)$ has no effect on the ATPase inhibition mediated by PBDE (1). These results are consistent with our previous data (Figure 2B).

Figure 4. PBDE (1) inhibits NS3 RNA binding. (A) Gel mobility shift assay to characterize the inhibition of NS3 binding to $\left[\gamma_{-}{ }^{32} \mathrm{P}\right]$ labeled ssRNA. RNA only control (lane 1), $300 \mathrm{nM}$ BSA instead of NS3 control (lane 2), NS3 protein (300 nM) and DMSO control (lane 3), and NS3 protein with increasing concentrations of PBDE (1) (lanes 4-8). (B) Graphical representation of the RNA binding inhibition shown in panel A.

A

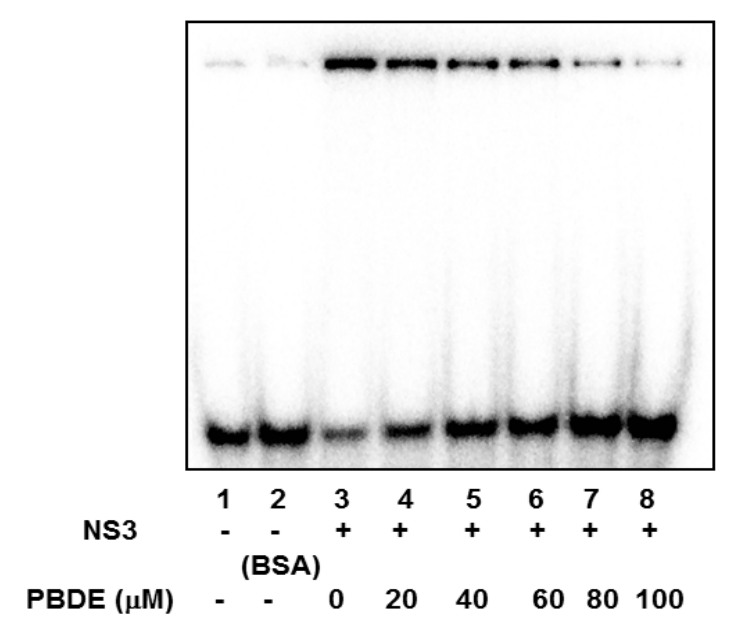

\section{B}

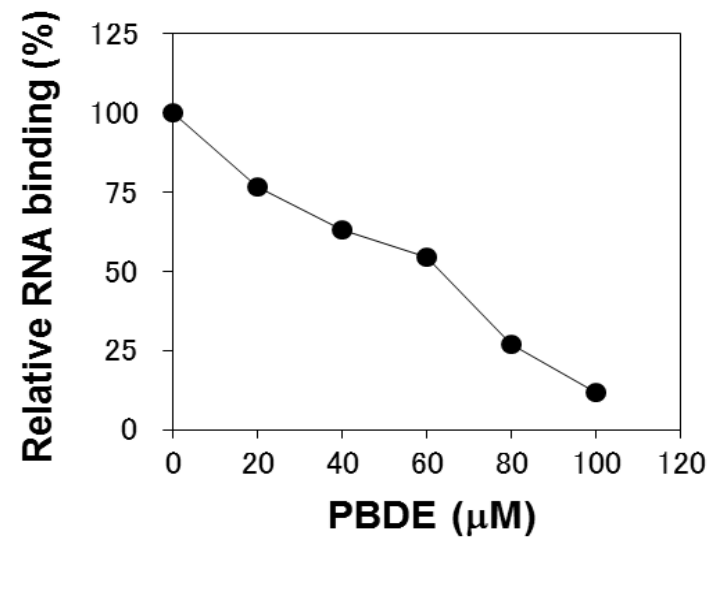

Figure 5. Effect of poly(U) RNA on NS3 ATPase activity. (A) ATPase assay with hydrolytic reaction buffer containing NS3 (600 nM), $1 \mathrm{mM}\left[\gamma_{-}{ }^{32} \mathrm{P}\right] \mathrm{ATP}$, poly(U) RNA and PBDE $(0.1 \mathrm{mM})$ as indicated. (B) Graphical representation of data presented in (A). The solid and white bars represent NS3 and poly(U) ATPase reactions performed with DMSO and PBDE (1), respectively. The assay was performed in triplicate and data are presented as mean \pm standard deviation. $* p>0.05$ and $* * p>0.01$ from Student $t$-test.

A

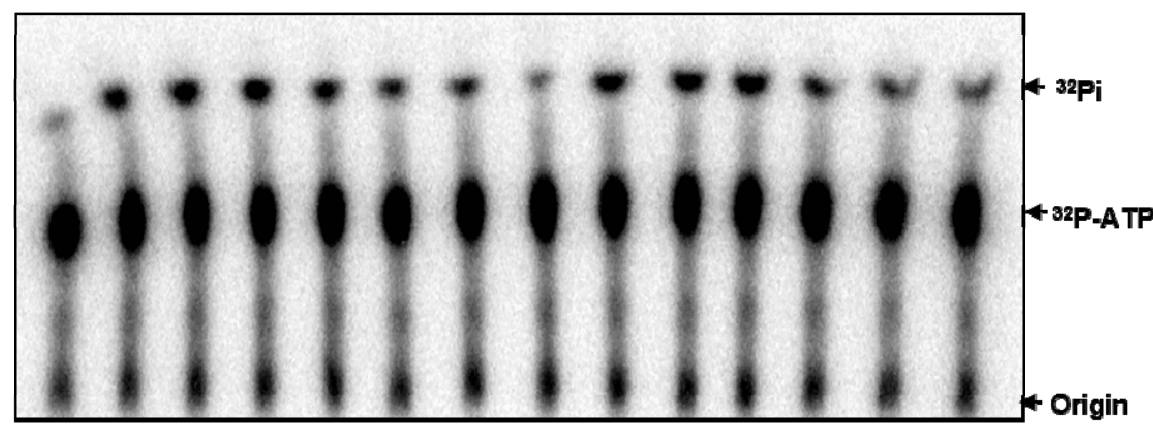

NS3 .

$\begin{array}{llllllllllllll}1 & 2 & 3 & 4 & 5 & 6 & 7 & 8 & 9 & 10 & 11 & 12 & 13 & 14\end{array}$

DMSO PBDE

Poly U - 
Figure 5. Cont.

\section{B}
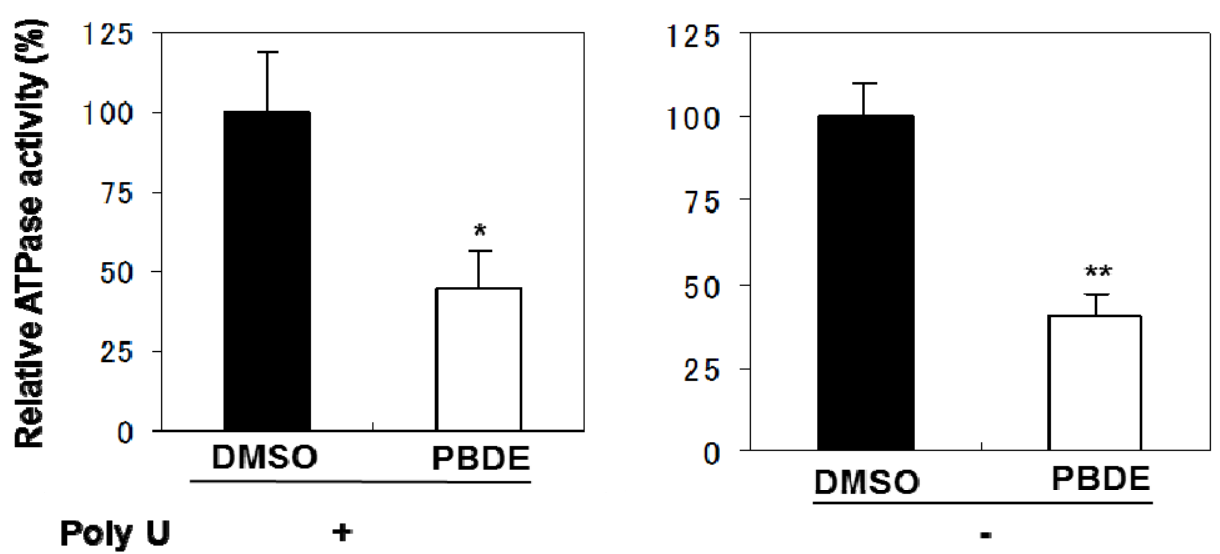

To clarify the structure-activity relationships of PBDE for inhibition of the ATPase activity of the NS3 protein, commercially available and natural phenol derivatives were examined (Table 2). We first investigated whether the hydroxyl group of PBDE (1) is required for ATPase activity. Substituting a methoxy group [25] (i.e., PBDE methyl ether 2) and a hydrogen (i.e., deoxy PBDE 17), for a phenolic hydroxyl group in PBDE led to a complete loss of the inhibitory activity. These findings indicated that the phenolic hydroxyl group has important effects on the inhibitory activity. Triclosan (4), which is structurally very close to PBDE, showed moderate levels of inhibition, indicating that bromine substituents on benzene rings can be replaced by chlorine substituents.

Table 2. Inhibition of the ATPase activity of the NS3 protein by PBDE (1) and its structurally related compounds.

\begin{tabular}{ccc} 
Compound No. & $\begin{array}{c}\text { Chemical Structure } \\
\text { (PBDE/related compounds) }\end{array}$ & $\begin{array}{c}\text { NS3 ATPase Inhibition } \\
\mathbf{I C}_{\mathbf{5 0}}(\mu \mathrm{M})\end{array}$ \\
\hline 1 & 80 \\
\hline
\end{tabular}


Table 2. Cont.

\begin{tabular}{|c|c|c|}
\hline Compound No. & $\begin{array}{c}\text { Chemical Structure } \\
\text { (PBDE/related compounds) }\end{array}$ & $\begin{array}{c}\text { NS3 ATPase Inhibition } \\
\text { IC }_{50}(\mu \mathrm{M})\end{array}$ \\
\hline 6 & & 120 \\
\hline 7 & & $>200$ \\
\hline 8 & & 54 \\
\hline 9 & & 94 \\
\hline 10 & & $>200$ \\
\hline 11 & & $>200$ \\
\hline 12 & & $>200$ \\
\hline 13 & & $>200$ \\
\hline 14 & & $>200$ \\
\hline 15 & & 54 \\
\hline 16 & & $>200$ \\
\hline 17 & & $>200$ \\
\hline
\end{tabular}


Next, we took into consideration the size of the structural motif [biphenyl (compounds $\mathbf{3 , 7 , 1 1 , 1 5 )}$ compared to phenyl (compound 5) and fused ring (compound 10)]. Interestingly, the inhibitory activity of bromophene $\mathbf{3}$, a biphenyl derivative possessing bromine and phenolic hydroxyl groups, remained at the same level as that of PBDE (1). While $o$-hydroxybiphenyl 7 showed loss of the inhibitory activity, hydroxyl-pentachlorobiphenyl $\mathbf{1 5}$ displayed the most potent inhibitory activity of all the analogs in this study. Notably, an additional halogen substituent on the benzene ring led to a nearly two-fold increase in activity over bromophene 3 .

Furthermore, hydroxynonafluorobiphenyl 11 was also inactive. These findings suggested that both halogen, such as bromine and chlorine, and phenolic hydroxyl groups on benzene rings would be crucial for the inhibition of the ATPase activity of the NS3 protein. Unfortunately, tribromophenol 5 and dibromonaphthalenol $\mathbf{1 0}$ did not exhibit the inhibitory activity, indicating that the molecular frame could affect the activity level. Tetrahalobisphenols A, (compounds 6 and 9), showed the same level of inhibition as that of bromophene 3. Replacement of methoxy groups in tetrabromobisphenol A (6) with 2-hydroxyethoxy groups, i.e., the bisphenol A hydroxyethyl ether 14, brought about loss of activity. Dibromobinaphthol 8, a dimer of bromonaphthalenol 10, displayed the most potent activity, whereas isomeric bromobinaphthol 12 and tetrahydrobromobinaphthol 13 showed no activity. These findings indicated that the distance between halogen and phenolic hydroxyl groups has important effects on the inhibitory activity. 4-Bromophenyl-2,6-diphenylphenol 16 did not show inhibitory activity likely because of the steric hindrance around the phenolic hydroxyl group.

The $\log \mathrm{P}$ is a measure of the lipophilicity of an organic compound, and can be defined as the ratio of the concentration of the unionized compound at equilibrium between organic and aqueous phases. Studies have shown that many biological phenomena can be correlated with this parameter, such that structure-activity relationships may be deduced. The relationship between the $\mathrm{IC}_{50}$ and $\log \mathrm{P}$ of PBDE and its structurally related compounds $\mathbf{1}-\mathbf{1 7}$ is shown in Figure 6. Biphenyl ethers $\mathbf{1}$ and $\mathbf{4}$, biphenyls 3 and 15, tetrahalobisphenols A 6 and 9, and binaphthol 8 with a $\log \mathrm{P}$ of over approximately 5 were located at the upper left, indicating the inhibitory activity. The inhibitory potency of halogenated phenols on the ATPase might increase with growing lipophilicity. Therefore, we have identified PBDE (1) and related compounds, hydroxypentachlorobiphenyl and dibromobinaphthol, as potent inhibitors of the HCV ATPase.

Figure 6. The relationships between $\log \mathrm{P}$ and $\mathrm{IC}_{50}$ values of the compounds.

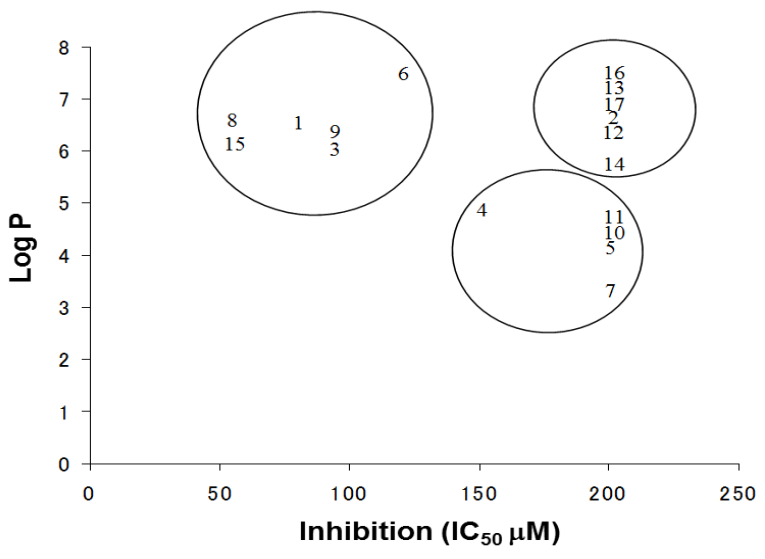


Finally, we examined the effects of PBDE (1) on HCV replication. As shown in Figure 7, PBDE (1) suppressed HCV replication in a dose-dependent manner $\left(\mathrm{EC}_{50}=3.3 \mu \mathrm{M}\right)$ without cytotoxic effect $\left(\mathrm{CC}_{50}>5 \mu \mathrm{M}\right)$.

Figure 7. Effect of PBDE (1) on viral replication. The subgenomic replicon RNA of genotype $1 \mathrm{~b} \mathrm{~N}$ strain was incubated in medium containing various concentrations of PBDE (1) or DMSO. Luciferase and cytotoxicity assays were carried out as described in Experimental section. Error bars indicate standard deviation. The data represent three independent experiments.

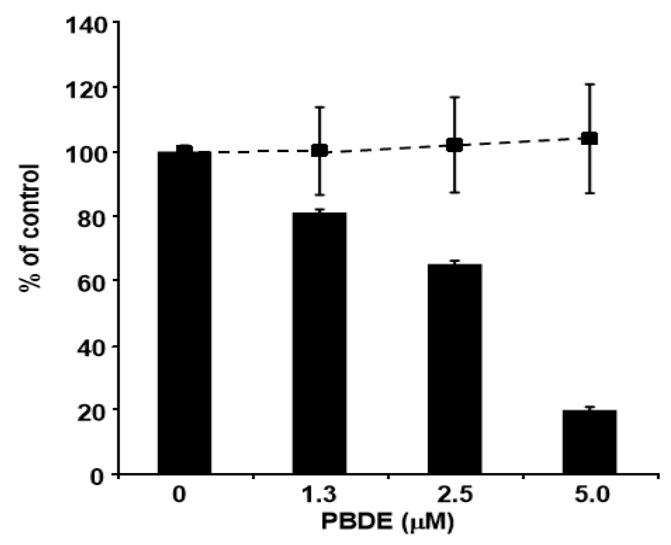

\section{Experimental}

\subsection{Chemicals and Reagents}

The $\gamma-{ }^{32} \mathrm{P}$-ATP isotope was purchased from Muromachi Yakuhin (Tokyo, Japan). Oligonucleotides were synthesized by Gene Design Inc. (Osaka, Japan). Bacterial alkaline phosphatase (BAPC75) was purchased from Takara Bio (Otsu, Japan). 6-hydroxy-2,2',4,4'-tetrabromodiphenyl ether (PBDE, 1) was isolated from a marine sponge, and compound $\mathbf{2}$ was obtained by methylation of compound $\mathbf{1}$ with trimethylsilyldiazomethane. Bromophene 3, triclosan (4), 2,4,6-tribromophenol (5), 3,3',5,5'-tetrabromobisphenol A (6), O-hydroxybiphenyl (7), 1,6-dibromo-2-naphthol (10), and 4,4'-isopropylidenebis[2-(2,6-dibromophenoxy)ethanol] (14) were purchased from Wako Pure Chemical (Osaka, Japan). Poly(U) RNA, 2,3,5,6-tetrafluoro-4-(pentafluorophenyl)phenol (11), $(R)$-(+)-3-3'-dibromo-1,1'-bi-2-naphthol (12), $(R)$-(+)-3,3'-dibromo-5,5',6,6',7,7',8,8'-octahydro-1,1'-bi2,2'-naphthalenediol (13), and 4-(4-bromophenyl)-2,6-diphenylphenol (16) were obtained from Sigma-Aldrich (St. Louis, MO, USA). (R)-(-)-6,6'-dibromo-1,1'-bi-2-naphthol (8) and tetrachlorobisphenol A (9) were purchased from TCI (Tokyo, Japan). 2-Hydroxy-2',3',4',5,5'-pentachlorobiphenyl (15) and 2,2',4,4'-tetrabromodiphenyl ether (17) were obtained from AccuStandard (New Haven, CT, USA).

\subsection{Extraction of $P B D E$}

The specimens used in this study were collected from marine organisms near Okinawa Islands, Japan (Table 1). Extractions were performed three times with either ethanol or acetone, and the ethyl-soluble portions (PM/SR-*-1) were obtained after concentration and partition. The aqueous layer 
was concentrated and methanol-soluble portions (PM/SR-*-2) were obtained by washing the residue and concentration.

\subsection{Screening for HCV NS3 Helicase Inhibitors}

The fluorescence helicase assay based on FRET was performed as described in our previous study [23]. The dsRNA substrate was prepared by annealing the 5' Alexa Fluor 488 labeled fluorescence strand (5'-UAGUACCGCCACCCUCAGAACCUUUUUUUUUUUUUU-3') to the $3^{\prime}$ BHQ1 labeled quencher strand (5'-GGUUCUGAGGGUGGCCCUACUA-3') at a 1:2 molar ratio. The dsRNA substrate has the 3'-overhang that is necessary for NS3 helicase to bind RNA prior to the duplex unwinding. The capture strand (5'-TAGTACCGCCACCCTCAGAACC-3'), which is complementary to the quencher strand, prevents the unwound duplexes from reannealing. None of the above three strands is self-complementary. The fluorescence and quencher strands were purchased from Japan Bio Services (Saitama, Japan). The capture strand was purchased from Tsukuba Oligo Service (Ibaraki, Japan). The reaction mixture contained $25 \mathrm{mM}$ MOPS-NaOH (pH 6.5), $3 \mathrm{mM} \mathrm{MgCl}, 2 \mathrm{mM}$ dithiothreitol, $4 \mathrm{U}$ of RNasin (Promega, WI, USA), $50 \mathrm{nM}$ dsRNA substrate, $100 \mathrm{nM}$ capture strand, $5 \mathrm{mM}$ ATP, an extract from a marine organism, and $240 \mathrm{nM} \mathrm{NS} 3$ in a total volume of $20 \mu \mathrm{L}$. Each extract from a marine organism diluted with DMSO was added to the reaction mixture at a final concentration in the range of $17.5-32.5 \mu \mathrm{g} / \mathrm{mL}$. The full-length HCV NS3 protein with serine protease and ATPase/helicase was expressed and purified as described previously [23].

The reaction was started by adding HCV NS3 helicase and performed at $37^{\circ} \mathrm{C}$ for $30 \mathrm{~min}$ using a LightCycler 1.5 (Roche Diagnostics, Basel, Switzerland). Fluorescence intensity was recorded every $5 \mathrm{~s}$ from 0 to $5 \mathrm{~min}$, and then every $30 \mathrm{~s}$ from 5 to $30 \mathrm{~min}$. Helicase activity was calculated as the initial reaction velocity relative to that of the control without a sample but with DMSO.

\subsection{ATP Hydrolysis (ATPase) Assay}

Following our previous report [26], unless otherwise stated, the standard assay reaction $(10 \mu \mathrm{L})$ contained the following components: $25 \mathrm{mM}$ MOPS-NaOH (pH 7.0), $1 \mathrm{mM} \mathrm{DTT,} 5 \mathrm{mM} \mathrm{MgCl}_{2}$, $5 \mathrm{mM} \mathrm{CaCl}_{2}, 1 \mathrm{mM}\left[\gamma_{-}{ }^{32} \mathrm{P}\right]$ ATP, $300 \mathrm{nM} \mathrm{NS} 3$, and $0.1 \mu \mathrm{g} / \mu \mathrm{L}$ poly(U) with serial dilution of the tested compounds in DMSO. Samples were incubated at $37{ }^{\circ} \mathrm{C}$ for $10 \mathrm{~min}$, and the reaction was terminated by adding $15 \mu \mathrm{L}$ of stop solution (10 mM EDTA). A small portion $(2 \mu \mathrm{L})$ of reaction mixture was spotted on a PEI-cellulose TLC plate (Merck Millipore, Darmstadt, Germany) and developed by ascending chromatography in $0.75 \mathrm{M} \mathrm{LiCl} / 1 \mathrm{M}$ formic acid solution for $25 \mathrm{~min}$. The TLC plate was then air-dried, and applied to autoradiography measured by an Image Reader FLA-9000 and quantified by Multi Gauge V3.11 software (Fujifilm, Tokyo, Japan). For the bacterial alkaline phosphatase assay, the buffer provided with the kit (Takara Bio, Otsu, Japan) was used, and then subjected to the assay as described above.

\subsection{Gel Mobility Shift Assay (GMSA)}

GMSA was performed with slight modification as described previously [26]. In brief, $\left[\gamma_{-}{ }^{32} \mathrm{P}\right]$ ATP-labeled single-stranded RNA $(0.4 \mathrm{nM})$ was incubated in a buffer containing $30 \mathrm{mM}$ Tris-HCl pH 7.5, 
$100 \mathrm{mM} \mathrm{NaCl}, 2 \mathrm{mM} \mathrm{MgCl} 2,1 \mathrm{mM}$ DTT, $20 \mathrm{U}$ of RNasin plus (Promega) in the presence of $300 \mathrm{nM} \mathrm{NS} 3$ protein with serial dilution of PBDE in DMSO at room temperature for $15 \mathrm{~min}$ in a final reaction volume of $20 \mu \mathrm{L}$. The protein-RNA complexes were loaded onto a 6\% native-PAGE (acrylamide:bis $=19: 1$ ) and after electrophoresis in TBE buffer, the labeled RNA bands were visualized and quantified with an Image Reader FLA-9000 (Fujifilm) and Multi Gauge V3.11 software (Fujifilm), respectively.

\subsection{HCV Replication Assay}

The cell lines harboring the subgenomic replicon RNAs of genotype $1 \mathrm{~b}$ strain $\mathrm{N}$ [27] were seeded at $2 \times 10^{4}$ cells per well in a 48 -well plate $24 \mathrm{~h}$ before treatment. The cells were treated with PBDE at various concentrations for $72 \mathrm{~h}$ and lysed in cell culture lysis reagent (Promega). A luciferase assay system (Promega) was used to determine the luciferase activity, and the luminescence was measured using Luminescencer-JNR AB-2100 (ATTO, Tokyo, Japan), corresponding to the expression level of the HCV replicon.

\subsection{Toxicity Assay}

MTS assay was carried out to determine cytotoxicity using a CellTiter 96 aqueous one-solution cell proliferation assay kit (Promega) according to the manufacturer's instructions.

\section{Conclusions}

In conclusion, the present study showed that PBDE (1) isolated from a marine sponge inhibited NS3 helicase through suppression of the ATPase and RNA binding activities. Moreover, PBDE (1) did not inhibit bacterial alkaline phosphatase, suggesting that PBDE (1) is specific for NS3 inhibition. Structure-activity relationships demonstrated that the biphenyl ring, bromine, and phenolic hydroxyl group on the benzene backbone might be crucial groups essential for the inhibitory potency.

\section{Acknowledgments}

This work was supported by MEXT KAKEN 22603007.

\section{Author Contributions}

Conceived and designed the experiments: M.T., N.A., H.T., N.N., S.T., Y.S. Performed the experiments: K.A.S., A.F., A.Y. Analyzed the data: K.A.S., M.T., N.A., K.M., M.N. Wrote the paper: K.A.S., M.T., N.A. Collected and identified the marine sponge: J.T., S.R.R.

\section{Conflicts of Interest}

The authors declare no conflict of interest. 


\section{References}

1. Choo, Q.L.; Kuo, G.; Weiner, A.J.; Overby, L.R.; Bradley, D.W.; Houghton, M. Isolation of a cDNA clone derived from a blood-borne non-A, non-B viral hepatitis genome. Science 1989, 244, 359-362.

2. Gravitz, L. Introduction: A smouldering public-health crisis. Nature 2011, 474, S2-S4.

3. Poordad, F.; McCone, J., Jr.; Bacon, B.R.; Bruno, S.; Manns, M.P.; Sulkowski, M.S.; Jacobson, I.M.; Reddy, K.R.; Goodman, Z.D.; Boparai, N.; et al. Boceprevir for untreated chronic HCV genotype 1 infection. N. Engl. J. Med. 2011, 364, 1195-1206.

4. Bacon, B.R.; Gordon, S.C.; Lawitz, E.; Marcellin, P.; Vierling, J.M.; Zeuzem, S.; Poordad, F.; Goodman, Z.D.; Sings, H.L.; Boparai, N.; et al. Boceprevir for previously treated chronic HCV genotype 1 infection. N. Engl. J. Med. 2011, 364, 1207-1217.

5. Jacobson, I.M.; McHutchison, J.G.; Dusheiko, G.; di bisceglie, A.M.; Reddy, K.R.; Bzowej, N.H.; Marcellin, P.; Muir, A.J.; Ferenci, P.; Flisiak, R.; et al. Telaprevir for previously untreated chronic hepatitis C virus infection. N. Engl. J. Med. 2011, 364, 2405-2416.

6. Zeuzem, S.; Andreone, P.; Pol, S.; Lawitz, E.; Diago, M.; Roberts, S.; Focaccia, R.; Younossi, Z.; Foster, G.R.; Horban, A.; et al. Telaprevir for retreatment of HCV infection. N. Engl. J. Med. 2011, 364, 2417-2428.

7. Takamizawa, A.; Mori, C.; Fuke, I.; Manabe, S.; Murakami, S.; Fujita, J.; Onishi, E.; Anodoh, T.; Yoshida, I.; Oakayama, H. Structure and organization of the hepatitis C virus genome isolated from human carriers. J. Virol. 1991, 65, 1105-1113.

8. Kai, L. Development of novel antiviral therapies for hepatitis C virus. Virol. Sin. 2010, 25, 246-266.

9. Moradpour, D.; Penin F.; Rice, C.M. Replication of hepatitis C virus. Nat. Rev. Microbiol. 2007, 5, 453-463.

10. Rice, C.M. New insights into HCV replication: Potential antiviral targets. Top. Antivir. Med. 2011, 19, 117-120.

11. De Francesco, R.; Steinkühler, C. Structure and function of the hepatitis C virus NS3-NS4A serine proteinase. Curr. Top. Microbiol. Immunol. 2000, 242, 149-169.

12. Raney, K.D.; Sharma, S.D.; Moustafa, I.M.; Cameron, C.E. Hepatitis C virus non-structural protein 3 (HCV NS3): A multifunctional antiviral target. J. Biol. Chem. 2010, 285, 22725-22731.

13. Ghany, M.G.; Nelson, D.R.; Strader, D.B.; Thomas, D.L.; Seeff, L.B. An update on treatment of genotype 1 chronic hepatitis $\mathrm{C}$ virus infection: 2011 practice guideline by the American Association for the Study of Liver Diseases. Hepatology 2011, 54, 1433-1444.

14. Hanif, N.; Tanaka, J.; Setiawan, A.; Trianto, A.; de Voogd, N.J.; Murni, A.; Tanaka, C.; Higa, T. Polybrominated diphenyl ethers from the Indonesian sponge Lamellodysidea. herbacea. J. Nat. Prod. 2007, 70, 432-435.

15. Sharma, G.M.; Vig, B. Studies on the antimicrobial substances of sponges. Structures of two antibacterial substances isolated from the marine sponge Dysidea. Herbacea. Tetrahedron Lett. 1972, 17, 1715-1718.

16. Salva, J.; Faulkner, D.J. A new brominated diphenyl ether from a Philippine Dysidea. species. J. Nat. Prod. 1990, 53, 757-760. 
17. Handayani, D.; Edrada, R.A.; Proksch, P.; Wray, V.; Witte, L.; van Soest, R.W.; Kunzmann, A.; Soedarsono. Four new bioactive polybrominated diphenyl ethers of the sponge Dysidea. herbacea from West Sumatra, Indonesia. J. Nat. Prod. 1997, 60, 1313-1316.

18. Sionov, E.; Roth, D.; Sandovsky-Losica, H.; Kashman, Y.; Rudi, A.; Chill, L.; Berdicevsky, I.; Segal, E. Antifungal effect and possible mode of activity of a compound from the marine sponge Dysidea. herbacea. J. Infect. 2005, 50, 453-460.

19. Hattori, T.; Konno, A.; Adachi, K.; Shizuri, Y. Four new bioactive bromophenols from the palauan Sponge Phyllospongia. dendyi. Fish. Sci. 2001, 67, 899-903.

20. Fu, X.; Schmitz, F.J.; Govindan, M.; Abbas, S.A.; Hanson, K.M.; Horton, P.A.; Crews, P.; Laney, M.; Schatzman, R.C. Enzyme inhibitors: New and known polybrominated phenols and diphenyl ethers from four Indo-pacific Dysidea. sponges. J. Nat. Prod. 1995, 58, 1384-1391.

21. Liu, H.; Namikoshi, M.; Meguro, S.; Nagai, H.; Kobayashi, H.; Yao, X. Isolation and characterization of polybrominated diphenyl ethers as inhibitors of microtubule assembly from the marine sponge Phyllospongia. dendyi collected at Palau. J. Nat. Prod. 2004, 67, 472-474.

22. Xu, Y.; Johnson, R.K.; Hecht, S.M. Polybrominated diphenyl ethers from a sponge of the Dysidea. genus that inhibit Tie2 kinase. Bioorg. Med. Chem. 2005, 13, 657-659.

23. Tani, H.; Fujita, O.; Furuta, A.; Matsuda, Y.; Miyata, R.; Akimitsu, N.; Tanaka, J.; Tsuneda, S.; Sekiguchi, Y.; Noda, N. Real-time monitoring of RNA helicase activity using fluorescence resonance energy transfer in vitro. Biochem. Biophys. Res. Commun. 2010, 393, 131-136.

24. Suzich, J.A.; Tamura, J.K.; Palmer-Hill, F.; Warrener, P.; Grakoui, A.; Rice, CM.; Feinstone, S.M.; Collett, M.S. Hepatitis C virus NS3 protein polynucleotide-stimulated nucleoside triphosphatase and comparison with the related pestivirus and flavivirus enzymes. J. Virol. 1993, 67, 6152-6158.

25. Capon, R.; Ghisalberti, E.L.; Jefferies, P.R.; Skelton, B.W.; White, A.H. Structural studies of halogenated diphenyl ethers from a marine sponge. J. Chem. Soc. Perkin Trans. 1. 1981, 2464-2467.

26. Salam, K.A.; Furuta, A.; Noda, N.; Tsuneda, S.; Sekiguchi, Y.; Yamashita, A.; Moriishi, K.; Nakakoshi, M.; Tsubuki, M.; Tani, H.; et al. Inhibition of hepatitis C virus NS3 helicase by manoalide. J. Nat. Prod. 2012, 75, 650-654.

27. Yokota, T.; Sakamoto, N.; Enomoto, N.; Tanabe, Y.; Miyagishi, M.; Maekawa, S.; Yi, L.; Kurosaki, M.; Taira, K.; Watanabe, M.; et al. Inhibition of intracellular hepatitis C virus replication by synthetic and vector-derived small interfering RNAs. EMBO Rep. 2003, 4, 602-608.

Sample Availability: Samples of the compounds are not available from the authors.

(C) 2014 by the authors; licensee MDPI, Basel, Switzerland. This article is an open access article distributed under the terms and conditions of the Creative Commons Attribution license (http://creativecommons.org/licenses/by/3.0/). 